\title{
A DIFFERENT LOOK OVER THE FINANCIAL DEPTH NONLINEARITY: EVIDENCE FROM EUROPE
}

\author{
UMA PERSPECTIVA DIFERENTE SOBRE A NÃO LINEARIDADE DO \\ DESENVOL VIMENTO FINANCEIRO: O CASO DA EUROPA
}

\author{
José Alberto Fuinhas ${ }^{1}$ \\ António Cardoso Marques ${ }^{2}$ \\ Ricardo Carreira ${ }^{3}$
}

\begin{abstract}
The nonlinear relationship between Economic Growth and Financial Depth was assessed for a panel of 25 European countries, for the period from 1996 to 2011. These countries share common spatial patterns as was confirmed by the presence of cross-sectional dependence. Furthermore, heteroskedasticity and first order autocorrelation are present in the panel. The Hausman test supports the presence of heterogeneity by selecting the fixed effects model. Accordingly, the robust estimator for these phenomena, the Driscoll and Kraay with fixed effects was used. The nonlinearity of the relationship was confirmed by the Utest of Lind and Mehlum. In short, results confirmed that excess financial development constrains growth for European countries. The optimal dimension of the financial sector should be considered by policymakers.
\end{abstract}

\section{RESUMO}

A relação não linear entre Crescimento Econômico e Profundidade Financeira foi avaliada com recurso a um painel de 25 países europeus, para o período compreendido entre 1996 e 2011. Estes países partilham padrões espaciais comuns como foi confirmado pela presença de dependência seccional. Além disso, foi identificado heterocedasticidade e autocorrelação de primeira ordem no painel. O teste de Hausman suporta a presença de heterogeneidade, selecionando o modelo de efeitos fixos. Foi utilizado o estimador Driscoll e Kraay com efeitos fixos, que é robusto a estes fenômenos. A não linearidade da relação entre Crescimento Econômico e Profundidade Financeira foi confirmada pelo U-teste de Lind e Mehlum. Pode-se concluir que o incremento na profundidade financeira restringe o Crescimento Economico para os países europeus. Como tal, a dimensão ótima do sector financeiro deve ser considerada pelos decisores de política econômica.

Palavras-chave: Finanças, linearidade, Europa

\footnotetext{
${ }^{1}$ Phd in Economy from University of Beira Interior. Professor of Departament of Administration and Economy of University of Beira Interior. E-mail: fuinhas@ubi.pt

${ }^{2}$ Phd in Economy of Porto University. Professor of Departament of Administration and Economy of University of Beira Interior. E-mail: amarques@ubi.pt

${ }^{3}$ Master's Degree in Economy of University of Beira Interior. E-mail: ricardo.ffc@hotmail.com
}

Revista de Estudos Sociais IAno 2015 N.34. V.17 
Keywords: Finance, linearity, Europe

JEL: C23, G00, O40

\section{INTRODUCTION}

The relationship between Financial Depth (FD) and Economic Growth (EG) goes back to the early 19th century, and Schumpeter (1934), Robinson (1952), Goldsmith (1969), McKinnon (1973) and Shaw (1973) among others, have documented this issue. This earlier seminal literature on FD reveals a lack of consensus that has persisted over time. Indeed, it concludes that financial intermediaries could promote economic efficiency leading to EG (Levine, 1997), or it could lead to the reverse (e.g. Demetriades and Hussein, 1996). Moreover, the impact of FD on EG remains a hot topic in literature. The literature has evolved to capture the relative dimension of finance in the economy. This financial dimension has been used in research through indicators, such as the size of banks, financial institutions and financial markets. In fact, the FD can be aggregated and related to output. The FD-EG nexus remains largely inconclusive for developed economies. This lack of consensus is manifested in differing opinions on the direction of causality and its specifications. This paper is looking for answers to the questions: (i) is there a relationship between EG and FD in Europe? and (ii) if this relationship exists, what is its functional form? It is important to consider this nexus in order to understand its impact on the economy and evaluate whether there is some kind of threshold beyond which FD promotes slower EG.

This article contributes to deepening the understanding of the relationship between the development of finance and EG, for developed economies, by analyzing the case of European countries. To disentangle the FD-EG nexus in developed economies, the European Union countries which have available data for the time span from 1996 to 2011 were used. The model included variables such as Gross Domestic Savings and the Ratio of Private Sector Credit to Gross Domestic Product to measure FD, and Governmental Expenditures, Commercial Balance, Electricity Consumption and Inflation in order to control for other interactions that are necessary for FD-EG nexus analysis. Particular attention was given to the construction of the variable that measures FD, and robust econometric techniques were used. We innovated by adding the dimension of energy consumption to the nexus. The Hausman test selected the Fixed Effects (FE) model as the most suitable for the estimation. Heteroskedasticity and cross-sectional dependence were found for the panel of countries, and consequently the Driscoll and Kraay (1998) estimator (DK) was used. Commercial balance, government expenditures, and electrification are drivers for growth. Conversely, there was a negative effect on inflation, and on 
FD. An inverted U-shape form was confirmed for FD through the U-test from Lind and Mehlum (2010).

The rest of the paper is organized as follows: Section 2, review of the literature. Section 3 describes data. Section 4 centres on empirical methodology. In section 5, the results are discussed. Section 6 presents the conclusions.

\section{LITERATURE REVIEW}

In the last century, FD and EG received several contributions. Since the first approaches by Schumpeter (1934), Robinson (1952), Goldsmith (1969), McKinnon (1973) and Shaw (1973), the literature has attempted to provide sustained theories to explain the FD-EG nexus (e.g. Luintel and Khan, 1999; Levine, 2005; and Zingales, 2015). Economic theory suggests that FD has a significant role in growth. In fact, when the number of financial institutions and instruments increases, this contributes to reducing the cost of transactions and information. Thus, developed financial markets help economic agents to trade and diminish transaction risks. These conditions increase investments and stimulate economic growth (Masten et al., 2008). However, the existence of some constraints, such as geographic, temporal, financial and methodological conditions, allows a nonlinear relationship to be revealed between the variables (De Gregorio and Guidotti, 1995). These authors, along with Demetriades and Hussein (1996) were the first to document the nonlinearity in the FD-EG nexus.

Berthelemy and Varoudakis (1996) introduced the concept of limits to FD. Based on this study, Rioja and Valev (2004) split countries into groups and established critical values for these limits. This allowed them to determine the different phases of the impact of FD on EG. Following this path, we can find in the first instance that it is necessary to achieve a minimum financial development value to register EG. Subsequently, especially in smaller economies, there is a sharp increase in EG, followed by a steady state of the process and, finally, a downturn in the process, i.e. FD slowing down EG. In the literature, some authors also find that financial depth has no impact on economic growth (See Greenwood and Jovanovic, 1990; Lee, 1996; Acemoglu and Zilibotti, 1997; Deida and Fattouh, 2002; Rioja and Valev, 2004; and Kim and Lin, 2011).

Establishing the threshold beyond which the FD-EG nexus becomes negative when it exceeds a certain percentage of GDP is a common practice in the literature. The critical value of Domestic Credit provided by the Banking Sector (DCBS) to output, is around $90 \%$ (Cecchetti and Kharroubi, 2012; and Law and Singh, 2014), and for the ratio of private credit to GDP, this limit is $110 \%$ (Aracand et al., 2012). The size of countries is also an important factor in stimulating EG. Countries with lower income levels achieve EG through capital accumulation and are better suited to generating growth through FD than those 
which generate $E G$ from increasing productivity, i.e. those with higher levels of income (e.g. De Gregorio and Guidotti, 1995; Deidda and Fattouh, 2002; and Rioja and Valev, 2004).

For Bumann et al. (2013) financial liberalization and development of financial markets have a positive impact on EG. However these two subjects are related and share a common concern; both can either promote EG or the reverse, i.e. they are nonlinear. When financial liberalization policies are applied, financial intermediaries face an increase in asymmetric information and a cut in profit margins which may lead to a financial crash (e.g. Hellmann et al., 2000; Bumann et al., 2013). Financial markets can also constrain EG by putting extra pressure on banks. Banks respond with lower interest rates, leading to a change in consumption habits (Carreira and Silva, 2010). Smaller interest rates raise current consumption and lower savings, and in addition, the retrenchment of investment leads to lower rates of EG. Rodrik and Subramanian (2009) analysed the links between long-run economic growth and financial globalization, and concluded that financial globalization could lower economic growth in developing countries.

Using a cross-country approach, the literature highlights the importance of FD to EG. Guiso et al. (2004) pointed out that the development of financial markets through financial integration is important to achieve growth. Rioja and Valev (2004) identified different levels of relationship between EG and FD inside the same country. Deidda and Fattouh (2002) found a significant impact of finance on growth in high-income countries, and an insignificant impact in low-income countries. Klein and Olivei (2008) found that countries that opened capital accounts had increased financial depth and greater economic growth. These latter authors also considered that these results were driven by the developed countries included in the sample.

More recently, literature has been focusing on this issue of a nonlinear relationship within the FD-EG nexus. Arcand, (2012) and Samargandi et al. (2015) have similarly concluded that FD promotes EG, but only to a certain extent. Moreover, FD has an impact on growth that is positive in the long-run but negative in the short-run (Loayza and Ranciére, 2006). This trend means that at a certain point, financial growth starts to become excessive, eroding EG, and policy makers need to introduce measures to reverse this process. The impact of financial depth on economic growth appears to fade away over time. Samples with longer time spans demonstrate that FD is more significant to EG, while in recent samples it is less significant (Rousseau and Wachtel, 2011). The scarcity of literature on developed countries that involves electrification as a measure of economic sophistication, has inspired the present study. 


\section{DATA DECRIPTION}

For analysis of the FD-EG nexus in developed countries, annual frequency data from 1996 to 2011 was used for a group of 25 European countries. These countries share strong financial integration, namely Belgium, Bulgaria, Cyprus, the Czech Republic, Germany, Denmark, Estonia, Finland, France, the United Kingdom, Greece, Croatia, Hungary, Ireland, Italy, Lithuania, Latvia, Malta, the Netherlands, Poland, Portugal, Romania, Slovenia, Spain and Sweden. The period and countries chosen, resulted from the availability of data and the trade-off between more years and less countries, and vice versa. This choice resulted in the exclusion of Austria, Slovakia and Luxembourg from the analysis.

In the literature, there is a lack of consensus regarding which variables should be used to measure FD and EG. This lack of consensus is mainly due to the econometric methodologies used, the time span, or the group of countries analyzed (e.g. Ang and McKibbin, 2007; Jalil and Feridun, 2011; Kim and Lin, 2011; Singh and Huang, 2011; Rewilak, 2013; Samargandi et al., 2015). The study began with the variables commonly used in FD literature and electrification as a proxy of economic development.

Gross Domestic Product per capita at constant 2005 US\$ (GDPPC) was used as a dependent variable to check the FD-EG nexus in Europe. Additional independent variables were introduced, namely Domestic Credit Provided by the Banking Sector (DCBS), Domestic Credit Provided by the Private Sector (DCPS), Commercial Balance (TRADE), General Government Final Consumption Expenditure (GOV), Electrification (E) and Inflation (CPIINF). The first two independent variables, as explained later, are aggregated to measure FD (generating the variable FD2SQ), TRADE and GOV are used to determine the impact of fiscal policy, CPIINF controls price distortion and a new variable, electrification, is introduced as a proxy of a country's general economic sophistication, i.e. emulating the absent variables. The variables GDPPC, FD2SQ, TRADE and GOV were extracted from the World Development Indicators (WDI). The CPIINF (first differences of national consumer price index - all items) was downloaded from AMECO and Electrification (Total Electricity Net Consumption) from the Energy Information Administration (EIA). The usage of GOV as final expenditure was employed by following the methodology of Hassan et al. (2011). Moreover, variables were expressed in absolute values, and not as a percentage of GDP, to make it to easier to draw conclusions. Other variables such as globalisation, and capital account liberalization were used in literature by Rodrik and Subramanian (2009) and Klein and Olivei (2008), respectively. However, they note that these variables are essential to study developing countries, and these are not the 
subject of our study. Table 1 summarizes the respective descriptive statistics and the cross-section dependence (CSD) of the variables. For the variables, the prefix "L" denotes natural logarithms and the suffix "PC" per capita.

Table 1 - Variables description and descriptive statistics

\begin{tabular}{|c|c|c|c|c|c|c|c|c|}
\hline \multicolumn{6}{|c|}{ Descriptive Statistics } & \multicolumn{3}{|c|}{ Cross-section dependence } \\
\hline Variable & $\begin{array}{l}\mathrm{Ob} \\
\mathrm{s}\end{array}$ & Mean & SD & Min & Max & CD-test & Corr & $\begin{array}{l}\text { Abs(cor } \\
\text { r) }\end{array}$ \\
\hline LGDPPC & 400 & $\begin{array}{l}9.740 \\
1\end{array}$ & $\begin{array}{l}0.778 \\
5\end{array}$ & $\begin{array}{l}7.763 \\
8\end{array}$ & $\begin{array}{l}10.839 \\
6\end{array}$ & $63.94^{\star * *}$ & 0.923 & 0.923 \\
\hline FD2SQ & 397 & $\begin{array}{l}4.498 \\
2\end{array}$ & 5.415 & $\begin{array}{l}0.020 \\
2\end{array}$ & $\begin{array}{l}35.139 \\
3\end{array}$ & $50.14^{\star \star *}$ & 0.73 & 0.83 \\
\hline $\begin{array}{l}\text { LTRADEP } \\
\mathrm{C}\end{array}$ & 399 & $\begin{array}{l}9.653 \\
9\end{array}$ & $\begin{array}{l}0.814 \\
3\end{array}$ & $\begin{array}{l}7.468 \\
3\end{array}$ & $\begin{array}{l}11.331 \\
4\end{array}$ & $60.28^{* * *}$ & 0.872 & 0.872 \\
\hline LGOVPC & 399 & $\begin{array}{l}8.107 \\
0\end{array}$ & $\begin{array}{l}0.915 \\
9\end{array}$ & $\begin{array}{l}5.221 \\
2\end{array}$ & 9.5223 & $58.58^{\star \star \star}$ & 0.848 & 0.848 \\
\hline CPINF & 400 & $\begin{array}{l}4.956 \\
5\end{array}$ & $\begin{array}{l}14.29 \\
5\end{array}$ & $\begin{array}{l}- \\
4.589 \\
7\end{array}$ & 244.96 & $22.66^{\star * *}$ & 0.327 & 0.37 \\
\hline LEPC & 400 & -12.23 & $\begin{array}{l}0.475 \\
5\end{array}$ & $\begin{array}{l}- \\
13.20 \\
4\end{array}$ & $\begin{array}{l}11.008 \\
9\end{array}$ & $41.90^{* * *}$ & 0.605 & 0.684 \\
\hline
\end{tabular}

${ }^{* * *}$, denotes a level of significance of $1 \%$; the CSD test has $\mathrm{N}(0,1)$ distribution, under the $\mathrm{H} 0$ : cross-section independence; and the Stata command xtcd was used to achieve the results for CSD.

Building a variable to measure FD requires some care. Financial services are provided by several institutions and consequently, fully capturing the financial sector is far from straightforward. The literature suggests at least three ways to measure FD. All of them are measured as ratios to handle with the expected high multicollinearity between variables. The three measurements of FD are: (i) The ratio of M2 or M3 to GDP: the monetary aggregate that captures the net liabilities of the financial system. This measurement of FD has the drawback of ignoring the transactional power of channelling funds from financial sector deposits to investors (Ang and McKibbin, 2007). (ii) The ratio of 
private sector credit to GDP: which corresponds to the ratio of the sum of DCBS and DCPS, to GDP. This ratio captures the credit extended to the private sector, allowing the use of funds on more productive activities (Samargandi et al., 2015). This ratio may also capture the differences between credit conceded to state firms or governments, and the credit conceded to private firms to stimulate growth (King and Levine, 1993). (iii) The ratio of commercial bank assets to the sum of these assets plus central bank assets: this variable captures the dimension of the commercial banks in the financial system. This variable is used when it is presumed that the commercial banks are more efficient in channelling funds to more profitable investments than central banks (Ang and McKibbin, 2007); and (iv) Principal Component Analysis: This multivariate data analysis method extracts indexes, and aggregates them into a new variable. The purpose of this method is to retain significant data variation without correlation problems (Çoban and Topcu, 2013). Ratio (ii) was used to measure FD. The other ratios were excluded for the following reasons. Ratio (i) will most probably produce non-significant estimations, as it only reflects the ability of transaction services delivered by the financial system (Samargandi et al., 2015). Ratios (iii) and (iv) restrict the time period so, in the interest of having well balanced panel data, we excluded these hypotheses.

The polynomial shape of ratio (ii) is used to capture the nonlinear effect of FD. A high level of FD means a greater dependence on the financial system. A priori we expected to capture a nonlinear effect of FD on growth. Indeed, it is implausible to only achieve economic growth through growth of the financial system. Moreover, current studies have shown that the effect of the financial system vanishes over time (e.g. Arcand et al., 2012; Law and Singh, 2014). The econometric analysis was performed using Stata 13.1 software.

\section{METHODOLOGY AND PRELIMINARY TESTS}

It is well known that European countries share several common features. Therefore, panel data techniques are appropriate to control individual heterogeneity and the unobserved characteristics of errors, but attention must be paid to these phenomena. Following a similar methodology to that pursued by Marques and Fuinhas (2012), diagnostic tests were applied to assess the presence of phenomena of collinearity, multicollinearity, autocorrelation, CSD and heteroskedasticity. Regarding the collinearity assessment, both the correlation matrix and the individual and mean Variance Inflation Factor (VIF) are provided in table 2.

Table 2 - Correlation matrix and VIF statistics

\begin{tabular}{|c|c|c|}
\hline & LGDPPC FD2SQ & LTRADEPC LGOVPC CPIINF LEPC \\
\hline LGDPPC & 1.0000 & \\
\hline
\end{tabular}




\begin{tabular}{l|llllll} 
FD2SQ & 0.484346 & 1.0000 & & & & \\
LTRADEPC & 0.8828 & 0.4631 & 1.0000 & & & \\
LGOVPC & 0.9743 & 0.4687 & 0.8805 & 1.0000 & & \\
CPIINF & -0.3516 & -0.1476 & -0.3304 & -0.3758 & 1.0000 & \\
LEPC & 0.7610 & 0.1916 & 0.7110 & 0.7828 & -0.2062 & 1.0000 \\
\hline VIF & & 1.47 & 4.58 & 6.67 & 1.20 & 3.01
\end{tabular}

Mean VIF 3.39

The Wooldridge test confirms the presence of autocorrelation of the first order. The CSD was assessed through Pesaran, Friedman, and Frees tests. These tests were applied instead of the Breusch-Pagan LM test due to the characteristics of the sample, with more crosses than time periods (see Hoyos and Sarafidis, 2006). The results are inconclusive for both the FE model and the random effects (RE) model. The Pesaran and Friedman tests indicated the presence of CSD in contrast to the outcome of the Frees test. The Hausman test with the null hypothesis RE model as best option, was used to choose between the RE and FE models. This test indicated the FE model as being the most suitable. Moreover, the statistically highly significant Hausman p-value

$\left(\chi_{5}^{2}=36.33\right)$ supported rejection of the null hypothesis. Lastly, the modified Wald test revealed the presence of heteroskedasticity. Table 3 summarizes the diagnostic test results.

Table 3 - Diagnostic tests

\begin{tabular}{llll}
\hline & Pooled & FE & RE \\
\hline Wooldridge test & $146.977^{\star * *}$ & & \\
Pesaran's test & & $5.323^{* * *}$ & $4.711^{* * *}$ \\
Friedman's test & $47.029^{* * *}$ & $44.375^{\star * *}$ \\
Frees' test & 4.695 & 4.561 \\
Modified Wald test & $5092.09^{* * *}$ & \\
\hline
\end{tabular}

${ }^{\star \star *}$, represents a level of significance of $1 \%$; the Wooldridge test is normally distributed $\mathrm{N}(0,1)$ and tests the null hypothesis of no serial correlation; Pesaran, Frees and Friedman's tests test the null hypothesis of cross-section independence; Pesaran's test is a parametric testing procedure and follows a 
standard normal distribution; Frees' test uses Frees' Q-distribution; Friedman's test is a non-parametric test based on Spearman's rank correlation coefficient; the Modified Wald Test has $\chi^{2}$ distribution and tests the null hypothesis of: $\sigma_{c}^{2}=\sigma^{2}$, for $c=1, \ldots, N$; in the Wooldridge test the Stata command xtserial was used; in the Pesaran, Friedman and Frees tests the Stata command xtcsd with options abs was used; and in the Modified Wald test the Stata command xttes 3 was used.

Given the detection of CSD (table 1), the appliance of first generation unit root tests was unnecessary. Indeed, to appraise the order of integration of variables, the second-generation unit root test of the CIPS (Pesaran, 2007) was carried out. This test is robust to heterogeneity under a nonstandard distribution. From the CIPS test, the variables are integrated series of order zero, I(0). Table 4 shows the results of unit root tests.

Table 4 - Unit Root test

\begin{tabular}{l|llllll}
\hline Variables & LGDPPC & FD2SQ & $\begin{array}{l}\text { LTRADEP } \\
\text { C }\end{array}$ & $\begin{array}{l}\text { LGOVP } \\
\text { C }\end{array}$ & CPIINF LEPC \\
\hline CIPS (Zt-bar) & $-3.077^{* * *}$ & $-1.772^{* *}$ & $-1.700^{* *}$ & $-2.257^{* *}$ & $-4.729^{* * *}$ & - \\
$1.394^{*}$ \\
\hline
\end{tabular}
(2007) Panel Unit Root test (CIPS): series are I(0); lag(1) and no trend specifications were used; and the Stata command multipurt was used to compute CIPS.

The results of diagnostic tests (table 3 ) indicate that the DK estimator is the most suitable. Moreover, this estimator has the advantage of not restricting the size of crosses and time dimensions.

The follow model specification was used:

$$
\begin{aligned}
& L_{G D P P C}=\alpha_{1 i}+\beta_{11 i} F D 2 S Q_{i t}+\beta_{12 i} \text { LTRADEPC }_{i t} \\
& +\beta_{13 i} \text { LGOVPC }_{i t}+\beta_{14 i} C P I I N F_{i t}+\beta_{15 i} \text { LEPC }_{i t}+\varepsilon_{1 i t},
\end{aligned}
$$


where $a_{i}$ denotes the intercept and $e_{1}$ the error term.

After the model estimation, the U-test was applied to check the robustness of the results. This test has the advantage of detecting the form of the relationships between variables, i.e. in $U$ or inverted $U$-shape through an explanatory variable and a quadratic term.

\section{RESULTS AND DISCUSSION}

The DK, FE and the FE Robust only correct standard error parameters. Therefore, equal coefficients are expected. Table 5 synthesizes the main estimators used. We used the RE model as a benchmark.

Table 5 - Results from the estimators

Dependent variable LGDPPC

\begin{tabular}{|c|c|c|c|c|}
\hline Models & $\begin{array}{l}\text { DK } \\
\text { (I) }\end{array}$ & $\begin{array}{l}\mathrm{FE} \\
\text { (II) }\end{array}$ & $\begin{array}{l}\text { FE robust } \\
\text { (III) }\end{array}$ & $\begin{array}{l}\text { RE } \\
\text { (IV) }\end{array}$ \\
\hline Constant & $8.24706^{\star \star \star}$ & $8.24706^{\star \star \star}$ & $8.24706^{\star \star \star}$ & $7.60679^{\star \star \star}$ \\
\hline$\overline{\text { FD2SQ }}$ & $-0.00424^{\star \star \star}$ & $-0.00424^{\star \star \star}$ & $-0.00424^{\star \star \star}$ & $-0.00451^{\star \star \star}$ \\
\hline LTRADEPC & $0.36422^{\star \star \star}$ & $0.36422^{\star \star \star}$ & $0.36422^{\star \star \star}$ & $0.35365^{\star \star \star}$ \\
\hline LGOVPC & $0.28160^{\star \star \star}$ & $0.28160^{\star \star \star}$ & $0.28160^{\star \star \star}$ & $0.32689^{\star \star \star}$ \\
\hline CPIINF & $-0.00050^{\star \star}$ & $-0.00050^{\star \star}$ & -0.00050 & $-0.00039 \star \star$ \\
\hline LECPC & $0.35043^{\star \star \star}$ & $0.35043^{\star \star \star}$ & $0.35043^{\star \star \star}$ & $0.31963^{\star \star \star}$ \\
\hline \multicolumn{5}{|l|}{ Statistics } \\
\hline$\overline{\mathbf{N}}$ & 396 & 396 & 396 & 396 \\
\hline$R^{\wedge} 2$ & 0.9159 & 0.9159 & 0.9159 & 0.9152 \\
\hline $\mathbf{F}$ & 5711.02 & 797.17 & 130.27 & \\
\hline
\end{tabular}

${ }^{\star \star *},{ }^{* *},{ }^{*}$ denotes significance at 1,5 and $10 \%$, respectively; and the command xtscc with options FE and lag (1) was used on the DK estimation.

The results for the FD-EG nexus of our model, for Europe, are similar in nature to those of Samargandi et al. (2015) for middle-income countries, and 
Arcand et al. (2012) for low-income countries. Therefore, it seems that the nexus results are common throughout the world. As revealed in table 5, FD2SQ has a negative and statistically significant coefficient for all estimations. This could result from: (i) The thresholds proposed by Arcand et al. (2012) of 110\% for the ratio of private credit to GDP, or $90 \%$ for DCBS to GDP, were exceeded; (ii) Existing countries exclusively classified as upper middle income or highincome. As stated before, highly developed countries have demonstrated a slower transition from FD to EG.

As the literature points out, the impact of inflation on growth could be positive or negative, depending on the state of the economy (e.g. Eggoh and Khan, 2014). Indeed, the effect can be positive, resulting from an excess of demand and provoking a persistent rise of prices and potentially stimulating production, or negative due to its persistence and high values, potentially generating economic instability. Bearing in mind the group of countries selected, a negative coefficient was expected and detected. This result indicates that the instability effect is more predominant than that of excess demand. Low inflation provides macroeconomic stability and therefore stimulates EG. Another effect could be associated with the negative indication, i.e. it suggests that volatility depresses growth contrary to the prevalence of monetary illusion. Electrification (LEPC) has a positive effect on EG. Indeed this variable embodies the effect of energy, as both a resource and as an indication of economic sophistication/development. Indeed, in general a sophisticated economy is more electrified. Commercial balance (TRADE) contributes positively to the GDP. As expected, when countries open their economies, this induces EG. The GOV variable has a positive coefficient too. This result is also expected, because when a government uses fiscal policy it stimulates EG (Devarajan et al., 1996).

As mentioned before, a quadratic condition was applied to FD. The exclusive introduction of FD2SQ, instead of both variables, is related to the multicolinearity between them. The estimations made solely with FD, produce significant and positive coefficients, while with the quadratic term, the coefficients are significant and negative. This reinforces the nonlinear relationship between FD and EG. The U-test was carried out to confirm the existence of an inverted U-shape (the Stata command utest, with the option quadratic, was used). Table 6 shows the U-Test results.

Table 6 - U-Test

Statistics

Lower bound slope

$0.41540^{\star \star \star}$ 
Upper bound slope

Global test for inverted U-shape

${ }^{* * \star}$ denotes significance at $1 \% ; \mathrm{H}_{0}$ : Monotone or U-shape; $\mathrm{H}_{1}$ : Inverse U-shape.

The null hypothesis of a monotone relationship between FD and EG was rejected by the U-test, thus confirming an inverted U-shape relationship between FD and EG. This result means that the use of a polynomial shape for FD was relevant. The results found for Europe are consistent with other groups of countries, namely low income and middle-income countries, i.e. excess of FD can hamper EG (e.g. Rousseau and Wachtel, 2011; Law and Singh, 2014; Samargandi et al., 2015). The panel data with the DK estimator and the U-test confirm the nonlinearity of the relationship between FD and EG. The origin of this phenomenon of a relationship with an inverted U-shape, could arise from the financial liberalization that occurred during the late 1990's. In fact, the liberalizing of the financial sector might provoke instability in several ways, specifically by the restricted mark-ups, increased information asymmetries and competition that slow EG. Indeed, economies are more exposed and prone to financial crashes resulting in negative contributions by FD to EG (Bumann et al., 2013). Financial liberalization encourages another impact. Due to this process of liberalization, markets are pressured to reduce interest rates, encouraging an increase in non-productive consumption and lower levels of investment. An economy focused on current consumption tends to reduce the impact of FD on EG. Electrification is shown to be a driver of EG. The analysis of this nexus suggests the necessity of comprehensive models. Indeed, variables such as TRADE, GOV, inflation and electrification need to be considered.

\section{CONCLUSION}

This paper contributes to the literature by analyzing the nonlinear relationship between FD and EG in Europe. The measurement of FD substantiated by the ratio of private sector credit to GDP, was shown to be an effective driver of EG.

The DK estimator with FE was used on 25 European countries for the period from 1996 to 2011. A negative coefficient was found for FD and inflation. Moreover, commercial balance, general government final consumption expenditure, and electric consumption have a positive effect on EG. Addressing the U-test, we confirmed the presence of an inverted U-shape between FD and $E G$, i.e. in the long-run, finance harms growth so it is necessary to invert the tendency. In fact, policies aimed towards growth of the financial system are ineffective and imprudent. Policymakers must find an optimal dimension for FD and avoid exceeding it. Likewise, liberalization policies to provide bank 
competition and cut the excess of power in the financial sector are recommended to avoid a negative effect of FD on EG.

The research in this area will benefit from extending the analysis to other blocks of countries, and different time spans. Instead of financial proxies, Principal Component Analysis could be used in future studies. Furthermore, the role of electrification in the context of FD and EG needs to be further scrutinized.

\section{ACKNOWLEDGMENTS}

The financial support of the NECE-UBI - Research Unit in Business Science and Economics, sponsored by the Portuguese Foundation for the Development of Science and Technology, Ministry of Education and Science, is acknowledged. We are grateful to two anonymous referees for their useful comments.

\section{REFERENCES}

ACEMOGLU, D.; ZILIBOTTI F. (1997) Was Prometheus unbound by chance? Risk, diversification, and growth, Journal of Political Economy, 105, 709-751.

ANG, J. B.; MCKIBBIN, W. J. (2007) Financial liberalization, financial sector development and growth: Evidence from Malaysia, Journal of Development Economics, 84(1), 215-233.

ARCAND, J.; BERKES, E; PANIZZA, U. (2012) Too much finance?, International Monetary Fund, Research Department.

BERTHELEMY, J. C.; VAROUDAKIS, A. (1996) Financial Development, Policy and Economic Growth (1996) In: N. Hermes, R. Lensink, "Financial Development and Economic Growth: Theory and Experiences from Developing Countries" Routledge, London, 66-89.

BUMANN, S.; HERMES, N.; LENSINK, R. (2013) Financial liberalization and economic growth: A meta-analysis, Journal of International Money and Finance, 33, 255-281.

CARREIRA, C.; SILVA, F. (2010) No deep pockets: Some stylized empirical results on firms' Financial constraints, Journal of Economic Surveys, 24(4), 731-753.

CECCHETTI, G.; KHARROUBI, E. (2012) Reassessing the impact of finance on growth, BIS working paper, 381. 
ÇOBAN, S.; TOPCU, M. (2013) The nexus between financial development and energy consumption in the EU: A dynamic panel data analysis, Energy Economics, 39, 81-88.

DE GREGORIO, J.; GUIDOTTI, P. (1995) Financial development and economic growth World Development, 23(3), 433-448.

DEIDDA, L.; FATTOUH, B. (2002) Non-Linearity between finance and growth, Economics Letters, 74(3), 339-345.

DEMETRIADES, P.; HUSSEIN, K. (1996) Does financial development cause economic growth?, Journal of Development Economics 51(2), 385-409.

DEVARAJAN, S.; SWAROOP V.; ZOU, H.-F. (1996) The composition of public expenditure and economic growth, Journal of Monetary Economics, 37(2), 313-344.

DRISCOLL, J.; KRAAY, A. C. (1998) Consistent covariance matrix estimation with spatially dependent data, Review of Economics and Statistics, 80, 549-560.

GREENWOOD, J.; JOVANOVIC, B. (1990) Financial development, growth, and the distribution of income, Journal of Political Economy, 98, 1076-1107.

GOLDSMITH, R. W. (1969) Financial structure and development, Yale University Press, New Haven, CT.

GUISO, L.; JAPPELLI, T.; PADULA, M.; PAGANO, M. (2004) Financial market integration and economic growth in the EU, Economic Policy, 40, 523-577.

HASSAN, M. K.; SANCHEZ, B.; YU J-S. (2011) Financial development and economic growth: New evidence from panel data, The Quarterly Review of Economics and Finance, 51, 88-104.

HELLMANN, T.; MURDOCK, K.; STIGLITZ, J. E. (2000) Liberalization, moral hazard in banking and prudential regulation: are capital requirements enough?, American Economic Review, 90(1), 147-165.

DE HOYOS, R. E.; SARAFIDIS, V. (2006) Testing for cross-sectional dependence in panel-data models, The Stata Journal, 6(4), 482-496.

EGGOH, J. C.; KHAN, M. (2014) On the nonlinear relationship between inflation and economic growth, Research in Economics 68(2), 133-143.

JALIL, A.; FERIDUN, M. (2011) The impact of growth, energy and financial development on the environment in China: A cointegration analysis, Energy Economics, 33, 284-291. 
KIM, D. -H.; LIN, S. -C. (2011) Nonlinearity in the financial developmentincome inequality nexus, Journal of Comparative Economics, 39, 310-325.

KING, R. G.; LEVINE, R. (1993) Finance and growth: Schumpeter might be right, The Quarterly Journal of Economics, 108(3), 717-737.

KLEIN, M. W.; OLIVEI, G. P. (2008) Capital account liberalization, financial depth, and economic growth, Journal of International Money and Finance, 27 (6), 861-875.

LAW, S. H.; SINGH, N. (2014) Does too much finance harm economic growth?, Journal of Banking and finance, 41, 36-44.

LEE, J. (1996) Financial development by learning, Journal of Development Economics, 50, 147-164.

LEVINE, R. (1997) Financial development and economic growth: Views and agenda, Journal of Economic Literature, 35, 688-726.

LEVINE, R. (2005) Finance and Growth: Theory and Evidence, In Handbook of Economic Growth, ed. Philippe Aghion and Steve Durlauf, Volume 1, Chapter 12. pp. 865-934.

LIND, J. T.; MEHLUM, H. (2010) With or without U? The appropriate test for U-shaped relationship, Oxford Bulletin of Economics and statistics, 72(1), 109-118.

LOAYZA, N. V.; Rancière, R. (2006) Financial development, financial fragility, and growth, Journal of Money, Credit and Banking, 38(4), 10511076.

MARQUES, A. C.; FUINHAS, J. A. (2012) Are public policies towards renewables successful? Evidence from European countries, Renewable Energy, 44, 109-118.

MASTEN, A. B.; CORICELLI, F.; MASTEN, I. (2008) Non-linear growth effects of financial development: Does financial integration matter?, Journal of International Money and Finance, 27, 295-313.

MCKINNON, R. I. (1973) Money and Capital in Economic Development, Brookings Institution, Washington, DC.

PESARAN, M. (2007) A simple panel unit root test in the presence of cross-section dependence, Journal of Applied Econometrics, 22(2), 265-312.

REWILAK, J. (2013) Finance is good for the poor but it depends where you live, Journal of Banking \& Finance, 37, 1451-1459. 
RIOJA, F.; VALEV, N. (2004) Finance and the Sources of Growth at various stages of Economic Development, Economic Inquiry, 42 (1), 127-140.

ROBINSON, J. (1952) The Rate of Interest and Other Essays, Macmillan, London.

RODRIK, D.; SUBRAMANIAN, A. (2009) Why Did Financial Globalization Disappoint?, IMF Staff Papers, 56(1), 112-138.

ROUSSEAU, P. L.; WACHTEL, P. (2011) What is happening to the impact of financial deepening on economic growth?, Economic Inquiry, 49(1), 276288.

SAMARGANDI, N.; FIDRMUC, J.; GHOSH, S. (2015) Is the Relationship Between Financial Development and Economic Growth Monotonic? Evidence from a Sample of Middle-Income Countries, World development, 68, $66-81$.

SCHUMPETER, J. (1934) The Theory of Economic Development: An Inquiry into Profits, Capital, Credit, Interest, and the Business Cycle, Cambridge, MA, US: Harvard University Press (Translated from the 1911 original German, Theorie der wirtschaftlichen Entwicklung).

SHAW, E. S. (1973) Financial deepening in economic development, New York: Oxford University Press.

SINGH, R. J.; HUANG, Y. (2011) Financial Deepening, Property Rights and Poverty: Evidence from Sub-Saharan Africa, International Monetary Fund.

ZINGALES, L. (2015) Does Finance Benefit Society?, NBER Working Paper 20894.

Submetido em: 14/06/15

Aceito em: 19/09/2015 